\title{
HUBUNGAN KARAKTERISTIK DENGAN KETERDEDAHAN MEDIA MASSA PETANI JAMBU METE (Kasus Petani Jambu Mete Di Desa Neumatang Kecamatan Wetar Kabupaten Maluku Barat Daya)
}

\author{
Paulus M. Puttileihalat \\ Staf Pengajar Faperta UNPATTI, $\boldsymbol{e}$-mail: -
}

\begin{abstract}
ABSTRAK
Penelitian dilaksanakan pada bulan September sampai Oktober 2010, di Desa Neumatang Kabupaten Maluku Barat Daya, dengan tujuan untuk mengetahui hubungan karakteristik petani jambu mete dengan keterdedahan media massa. Metode penentuan responden yang digunakan dalam penelitian ini adalah proposive sampling, dimana responden diambil secara sengaja terhadap petani yang melakukan kegiatan usahatani tanaman jambu mete berjumlah 10 orang. data primer diperoleh melalui wawancara langsung dengan sampel dan pengisian daftar pertanyaan yang sudah disiapkan sebelumnya. Hasil penelitian disimpulkan bahwa tidak terdapat hubungan nyata antara karakteristik petani (umur, Pendidikan dan pengalaman) dengan keterdedahan petani pada media massa. Hal ini disebabkan karena walaupun semakin bertambahnya umur, tingginya tingkat pendidikan dan banyaknya pengalaman petani tidak didukung dengan ketersedian informasi jambu mete.
\end{abstract}

\section{Kata Kunci: Jambu Mete, Keterdedahan, Maluku Barat Daya}

\section{PENDAHULUAN}

\subsection{Latar Belakang}

Pembukaan Undang-Undang Dasar 1945 (UUD 1945) tersurat beberapa harapan dan sekaligus tujuan bangsa Indonesia yaitu untuk memajukan kesejahteraan umum, mencerdaskan kehidupan bangsa, dan mewujudkan suatu keadilan sosial bagi seluruh rakyat Indonesia. Pemerintah dan seluruh segenap rakyat Indonesia sama-sama berperan aktif untuk melakukan pembangunan, termasuk pembangunan pertanian.

Otonomi daerah sebagaimana tercantum dalam Undang-Undang Nomor 32 Tahun 2004 merupakan jaminan pelaksanaan pembangunan pertanian di daerah serta bertujuan untuk dapat mewujudkan dua hal, yaitu: (1) memberikan kewenangan yang lebih besar kepada masyarakat untuk mengambil keputusan sehingga keputusan yang diambil sesuai dengan kebutuhan hidup masyarakat setempat, (2) meningkatkan tingkat partisipasi lokal di dalam pembangunan. Tujuan utama dari kebijakan desentralisasi dan otonomi daerah adalah membuka akses yang lebih besar kepada masyarakat untuk berpatisipasi dalam proses pengambilan keputusan dan pelaksanaannya di daerah (Haeruman, 2005).

Kabupaten MBD merupakan salah satu wilayah di Provinsi Maluku yang memiliki potensi lahan yang baik untuk pengembangan produksi jambu mete. Jumlah produksi jambu mete dari Tahun 2006 sampai dengan Tahun 2008 terus mengalami peningkatan skala produksi, yaitu dari 204 ton/Ha menjadi 1.136 ton/Ha/Tahun (MBD Dalam Angka 2009). Data ini menyebutkan bahwa laju peningkatan volume produksi jambu mete dari tahun ke tahun mengalami peningkatan. Walaupun skala produksinya meningkat setiap tahun, namun petani di wilayah tersebut belum merasakan manfaat ekonomis bagi kehidupan rumah tangga mereka. Salah satu faktor penyebabnya adalah kurangnya informasi. Kurangnya informasi menyebabkan tingkat kontak petani dengan berbagai sumber informasi sangat terbatas dalam pelaksanaan kegiatan usahatani jambu mete. 


\subsection{Tujuan Penelitian}

Berdasarkan rumusan masalah di atas maka penelitian ini bertujuan untuk mengetahui hubungan karakteristik petani jambu mete dengan keterdedahan media massa.

\section{METODOLOGI PENELITIAN}

\subsection{Lokasi dan Waktu Penelitian}

Penelitian dilakukan di Desa Neumatang Kabupaten Maluku Barat Daya, dengan pertimbangan daerah ini memiliki tanaman jambu mete yang tumbuh dengan baik pada kondisi lahan yang kristis dengan temperatur suhu udara yang cukup tinggi. Penelitian dilaksanakan pada bulan September sampai dengan Oktober 2010.

\subsection{Metode Penentuan Responden}

Metode penentuan responden yang digunakan dalam penelitian ini adalah proposive sampling, dimana responden diambil secara sengaja terhadap petani yang melakukan kegiatan usahatani tanaman jambu mete berjumlah 10 orang.

\subsection{Definisi Operasional}

a. Umur adalah usia responden atau petani yang dihitung sejak dilahirkan sampai saat penelitian dilakukan (saat responden diwawancarai). Satuan umur dinyatakan dalam tahun, dan dibagi dalam tiga kategori: muda (30 - 42 tahun), baya (43 - 55 tahun),dan tua (56 - 68 tahun), yang diukur dengan menggunakan skala ordinal.

b. Pendidikan formal adalah jenjang sekolah yang pernah diikuti responden hingga dilakukannya wawancara. Pengukuran dengan kategori rendah (tamat SD) skor 1, sedang (tamat SMP) skor 2, dan tinggi (tamat SMA) skor 3, yang diukur dengan menggunakan skala ordinal.

c. Pengalaman usahatani adalah lamanya petani (tahun) menekuni kegiatan usaha minyak kayu putih dihitung mulai dari awal berusahatani minyak kayu putih sampai dengan saat penelitian dilakukan. Satuan pengalaman dinyatakan dalam tahun, dan dibagi dalam tiga kategori; rendah (2 - 6 tahun) skor 1 , sedang ( 7 - 11 tahun) skor 2 dan tinggi (12 - 16 tahun) skor 3, yang diukur dengan menggunakan skala ordinal. d. Keterdedahan pada media massa adalah intensitas responden untuk mendapatkan informasi dari aktivitas membaca, menonton, dan mendengarkan materi-materi yang disajikan oleh berbagai sumber informasi. Keterdedahan dihitung untuk masa satu minggu dalam jangka waktu enam bulan sebelum penelitian. Tingkat keterdedahan terdiri dari jenis media, frekuensi, dan isi pesan. Dibagi dalam tiga kategori; rendah (5 - 11) diberi skor 1 , sedang $(12-18)$ diberi skor 2, dan tinggi (19 - 25) diberi skor 3. Pengukuran dengan menggunakan skala ordinal .

\subsection{Pengumpulan Data}

Pengumpulan data dapat menggunakan sumber data primer dan sumber data sekunder. Teknik pengumpulan data primer diperoleh melalui wawancara langsung dengan sampel dan pengisian daftar pertanyaan yang sudah disiapkan sebelumnya. Keseluruhan data yang sudah dikumpulkan kemudian ditabulasi dan dianalisis secara kualitatif dan kuantitatif.

\section{PEMBAHASAN}

\subsection{Karakteristik Petani}

Karakteristik petani ialah ciri-ciri atau sifat-sifat yang dimiliki oleh seorang petani yang ditampilkan melalui pola pikir, pola sikap dan pola tindakan terhadap lingkungannya (Zulkarnain, yang diacu dalam Mislini, 2006). Ciri-ciri atau sifat-sifat yang dimiliki oleh petani meliputi beberapa faktor atau unsur-unsur yang melekat pada diri seseorang dapat dikatakan sebagai karakteristik petani. Peubah karakteristik petani dalam penelitian ini terdiri atas umur, tingkat pendidikan dan pengalaman usahatani. Kategori responden dari masing-masing indikator dilakukan dengan teknik analisis deskriptif (Arikanto,1998). Analisis deskriptif diharapkan dapat mampu menggambarkan karakteristik petani yang melaksanakan kegiatan usaha tanaman jambu mete di Desa Neumatang, Kecamatan Kecamatan Wetar, Kabupaten Maluku Barat Daya, Provinsi Maluku. Tabel 1 menunjukkan proporsi responden berdasarkan distribusi karakteristik petani jambu mete di Desa Neumatang. 
Tabel 1. Proporsi Responden Petani Jambu Mete Di Desa Neumatang Menurut Karakteristik Petani, Tahun 2010

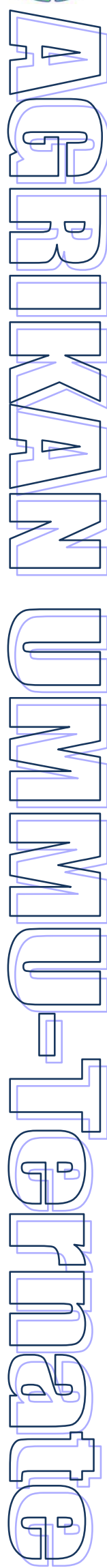

\begin{tabular}{llcc}
\hline Karakteristik Petani & \multicolumn{1}{c}{ Kategori } & $\begin{array}{c}\text { N } \\
\text { (Orang) }\end{array}$ & $\begin{array}{c}\text { Persentase } \\
(\%)\end{array}$ \\
& Muda (30-42) & 4 & 40 \\
Umur (Tahun) & Sedan/Baya (43-55) & 4 & 40 \\
& Tua (56-68) & 2 & 20 \\
\cline { 2 - 4 } & Jumlah & 10 & 100 \\
\hline Tingkat Pendidikan & Rendah (SD) & 5 & 50 \\
& Sedang (SMP) & 3 & 3 \\
& Tinggi (SMA) & 2 & 20 \\
\cline { 2 - 4 } & Jumlah & 10 & 100 \\
\hline Pengalaman Usahatani & Rendah (19-24) & 2 & 20 \\
(Tahun) & Sedang (25-30) & 5 & 50 \\
& Tinggi (31-35) & 3 & 30 \\
\cline { 2 - 4 } & Jumlah & 10 & 100 \\
\hline
\end{tabular}

Tabel 1 menunjukkan bahwa umur responden bervariasi antara 30 sampai dengan 68 tahun, dan jumlah terbanyak pada kategori muda dan baya masing-masing sebesar sebesar 40 persen. Berdasarkan umur responden, kelompok ini dapat dikatakan sebagai kelompok usia produktif ditinjau dari kemampuan melaksanakan pekerjaan.

Pendidikan formal petani paling banyak berada pada kategori rendah (SD) sebesar 50 persen. Hal ini disebabkan karena beberapa alasan, yaitu; kurang tersedianya sarana dan prasarana sekolah, transportasi laut untuk menghubungkan antar desa dan antar pulau sangat terbatas dan tidak adanya sarana dan prasarana jalan raya untuk transportasi darat yang menghubungkan antar desa maupun kecamatan.

Petani jambu mete di Desa Neumatang paling banyak memiliki pengalaman usahatani jambu mete berada pada kategori sedang sebanyak 50 persen. Hal ini menunjukkan bahwa rata-rata petani di Desa Neumatang sudah lama atau berpengalaman dalam mengusahakan tanaman jambu mete. Sehingga dapat diasumsikan bahwa semakin lama pengalaman seseorang (petani) maka semakin bertambah wawasan dan pengetahuan dalam kegiatan usaha tersebut.

\subsection{Keterdedahan Media Massa}

\subsubsection{Frekuensi Keterdedahan Media Massa}

Frekuensi menunjukkan berapa kali dalam seminggu petani menonton televisi, mendengarkan radio, membaca buku, dan membaca koran. Semakin banyak petani terdedah dengan media massa, maka berpengaruh pada perilaku petani untuk memperoleh informasi tentang tanaman jambu mete. Tabel 2 menunjukkan distribusi frekuensi keterdedahan petani pada media massa dalam jangka waktu satu minggu.

Tabel 2 menunjukkan bahwa keterdedahan petani pada media elektronik melalui televisi dengan persentase frekuensi menonton untuk kategori rendah menunjukkan 80 persen dimana petani hanya menonton satu sampai dengan tiga kali dalam seminggu, kategori sedang 10 persen di mana petani hanya menonton empat sampai dengan enam kali dalam seminggu, dan kategori tinggi 10 persen di mana petani menonton tujuh sampai dengan sembilan kali dalam seminggu. Frekuensi penggunaan radio oleh petani berada pada kategori rendah 10 persen di mana petani hanya mendengarkan siaran radio satu sampai dengan tiga kali dalam seminggu, kategori sedang 10 persen di mana petani hanya mendengarkan siaran radio empat sampai dengan enam kali dalam seminggu dan kategori tinggi 80 persen di mana petani mendengarkan siaran radio tujuh sampai dengan sembilan kali dalam seminggu. Pada umumnya, rata-rata petani menonton dan mendengarkan radio hanya pada sore hari untuk media radio dan malam hari untuk televisi. Perlu dijelaskan, bagi petani yang hanya memiliki radio dapat mendengarkan siaran tersebut hingga malam hari.

Tingkat keterdedahan petani pada media cetak melalui surat kabar hanya terdapat pada kategori rendah dan sedang, dengan persentase frekuensi membaca untuk kategori rendah menunjukkan 90 persen di mana frekuensi petani membaca surat kabar hanya nol (tidak membaca) sampai dengan dua kali dalam seminggu dan kategori sedang 10 persen, di mana frekuensi petani membaca tiga sampai dengan lima kali seminggu.Untuk waktu membaca disesuaikan 
dengan waktu istirahat petani, dan kondisi ini dapat berlangsung pada siang hari (waktu santai petani setelah istirahat bekerja) atau sore hari dan malam hari.

Berdasarkan uraian di atas dijelaskan bahwa minat petani dalam menonton televisi sangat rendah. Hal ini berhubungan dengan tingkat pemilikan pesawat televisi, dimana petani yang memiliki TV sepulang bekerja dari kebun dapat menonton tayangan acara di TV pada sore hingga malam hari. Sedangkan petani yang tidak memiliki TV rata-rata hanya dapat menonton tayangan acara TV dari sore samapai jam 20.00 WIT di rumah tetangga. Sedangkan untuk radio, rata-rata petani di desa tersebut sudah memiliki radio. Biasanya petani terdedah dengan radio pada sore hari stelah pulang dari kebun hingga malam hari. Untuk media cetak, tingkat keterdedahan petani terhadap media koran sangat rendah. Hal ini karena daerah tersebut belum terjangkau dengan media cetak (koran) dan kalaupun ada hanya terdapat pada tokoh masyarakat (kepala desa) yang melakukan kunjungan ke kota kabupaten.

Tabel 2. Distribusi frekuensi keterdedahan petani pada media massa

\begin{tabular}{|c|c|c|c|}
\hline \multirow{2}{*}{ Media Massa } & \multirow{2}{*}{ Kategori } & \multicolumn{2}{|c|}{ Jumlah } \\
\hline & & N (Orang) & Persentase (\%) \\
\hline \multicolumn{4}{|l|}{ Media Elektronik: } \\
\hline \multirow[t]{4}{*}{ Televisi } & Rendah (1-3 kali/minggu) & 8 & 80 \\
\hline & Sedang (4-6 kali/minggu) & 1 & 10 \\
\hline & Tinggi (7-9 kali/minggu) & 1 & 10 \\
\hline & Jumlah & 10 & 100 \\
\hline \multirow[t]{4}{*}{ Radio } & Rendah (1-3 kali/minggu) & 1 & 10 \\
\hline & Sedang (4-6 kali/minggu) & 1 & 10 \\
\hline & Tinggi (7-9 kali/minggu) & 8 & 80 \\
\hline & Jumlah & 10 & 100 \\
\hline \multicolumn{4}{|l|}{ Media Cetak: } \\
\hline \multirow[t]{4}{*}{ Surat Kabar } & Rendah (0-2 kali/minggu) & 9 & 90 \\
\hline & Sedang (3-5 kali/minggu) & 1 & 10 \\
\hline & Tinggi (6-8 kali/minggu) & - & - \\
\hline & Jumlah & 10 & 100 \\
\hline
\end{tabular}

\subsubsection{Hubungan Karakteristik Petani dengan Keterdedahan Media Massa}

Karakteristik petani dapat diukur dengan empat indikator, yaitu; umur, pendidikan, pengalaman usahatani dan status pekerjaan. Keterdedahan media massa (KMM) indikator yang digunakan adalah frekuensi keterdedahan petani pada media massa dalam jangka waktu satu minggu. Tabel 12 menjelaskan hubungan karakteristik petani dengan keterdedahan media massa, petani jambu metedi Desa Neumatang.

Tabel 4. Analisis hubungan antara karakteristik petani dengan keterdedahan media massa di Desa Neumatang, Tahun 2010

\begin{tabular}{clc}
\hline $\begin{array}{c}\text { Nama } \\
\text { Peubah }\end{array}$ & \multicolumn{1}{c}{ Indikator } & $\begin{array}{c}\text { Keterdedahan } \\
\text { Media Massa }\end{array}$ \\
\hline \multirow{2}{*}{ Karakteris } & Umur & 0.213 \\
tik Petani & Pendidikan & 0.116 \\
& Pengalaman Usahatani & 0.201 \\
\hline
\end{tabular}

Berdasarkan hasil uji statistik menunjukkan bahwa umur dengan keterdedahan media massa tidak berhubungan nyata pada taraf kepercayaan $95 \%$. Hal ini berarti setiap petani (baik dari kategori umur muda, baya maupun tua) kurang terdedah dengan media massa. Kurangnya keterdedahan petani terhadap media massa disebabkan karena sebagian besar petani tidak memiliki TV, koran maupun radio sehingga frekuensi mereka terdedah juga sangat rendah.

Berdasarkan hasil uji statistik menunjukkan bahwa hipotesa nol (H0) diterima dan hipotesa satu (H1) ditolak pada taraf kepercayaan 95 persen untuk analisis hubungan antara tingkat pendidikan dengan keterdedahan media massa. Berarti tidak terdapat hubungan nyata antara pendidikan dengan keterdedahan media massa petani untuk memperoleh informasi tentang jambu mete. Petani dengan latar pendidikan manapun, memiliki hak dan kesempatan yang sama untuk saling berhubungan memperoleh informasi jambu mete. Untuk memperoleh informasi jambu mete bukan dilihat dari tingginya pendidikan seseorang, namun didasarkan pada pengalaman yang merupakan sumber pengetahuan petani tentang obyek tersebut. Menurut Supriadi yang diacu dalam Zahid (1973), pengetahuan adalah sekumpulan informasi yang dipahami melalui proses belajar selama hidup dan dapat digunakan sewaktu- 
waktu sebagai alat penyesuaian diri sendiri maupun lingkungannya.

Berdasarkan hasil uji statistik menunjukkan bahwa pengalaman dengan keterdedahan media massa tidak berhubungan nyata. Semakin tinggi atau rendahnya pengalaman petani sama-sama memiliki tingkat keterdedahan terhadap media massa berada pada kategori rendah. Hal ini berkaitan dengan ketersediaan informasi pada media massa dimana televisi, radio dan surat kabar kurang menyediakan informasi yang menjadi kebutuhan petani (informasi jambu mete). Sehingga petani yang berpengalaman tinggi atau rendah samasama memanfaatkan televisi dan radio sebagai pengisian waktu senggang mereka setelah seharian bekerja begitu halnya dengan surat kabar.

\section{KESIMPULAN DAN SARAN \\ 4.1. Simpulan}

Berdasarkan hasil penelitian disimpulkan bahwa; tidak terdapat hubungan nyata antara karakteristik petani (umur, Pendidikan dan pengalaman) dengan keterdedahan petani pada media massa. Hal ini disebabkan karena walaupun semakin bertambahnya umur, tingginya tingkat pendidikan dan banyaknya pengalaman petani tidak didukung dengan ketersedian informasi jambu mete.

\subsection{Saran}

Berdasarkan hasil penelitian dan pembahasan disarankan; ketersediaan informasi tentang tanaman jambu mete perlu mendapat perhatian dari pemerintah daerah guna membantu petani dalam melakukan kegiatan usahanya di Desa Neumatang Kabupaten Maluku Barat daya.

\section{DAFTAR PUSTAKA}

Arikunto, S. 1998. Manajemen Penelitian. Rineka Cipta, Jakarta

BPS Provinsi Maluku, 2005. Provinsi Maluku dalam Angka 2005. Badan Pusat Statistik Provinsi Maluku.

Hatta, S. 2003. Budi Daya dan Penyulingan Kayu Putih. Penerbit Kanisius. Yogyakarta.

Haeruman, H. 2005. Kemitraan Dalam Pengembangan Ekonomi Lokal. Yayasan Mitra Pembangunan Desa-Kota dan BIC-Indonesia, Jakarta.

Mislini, 2006. Analisis Jaringan Komunikasi Pada Kelompok Swadaya Masyarakat. Kasus KSM di Desa Taman Sari, Kabupaten Bogor, Provinsi Jawa Barat. [Tesis]. Bogor: Program Pasca Sarjana, Institut Pertanian Bogor.

Zahid, A. 1997. Hubungan Karakteristik Peternak Sapi Perah dengan Sikap dan Perilaku Aktual dalam Pengelolaan Limbah Peternakan. [Tesis]. Bogor: Program Pasca Sarjana, Institut Pertanian Bogor. 